\title{
The research of enterpreneur cognition in strategic change
}

\author{
Zihui Zheng ${ }^{1,2}$, Xiaohu Zhou ${ }^{1}$ \\ ${ }^{1}$ School of economics and management, Nanjing University of Science and Technology, Nanjing, \\ Jiangsu 210094, China \\ ${ }^{2}$ Haier Group, Qingdao Shandong, 266101, China \\ Email: zihwei@163.com
}

Keywords: Enterpreneur cognition; strategic change; dynamic environment; positive correlation

\begin{abstract}
Under the background of rapid change in market demand, such as growth of competitors and technology innovation, strategy change becomes inevitable choice for sustainable development of enterprises.To be successful in implementation of strategy change, we need to study influence factors of strategy change deeply. This paper uses the theory of bounded rationality, social cognitive theory and knowledge creation theory to analyse the cognition between relationship entrepreneurial and strategic change. The results show that there are different dimensions in the process of entrepreneurial cognition and strategic change. Specifically, the allocation of cognition has a direct positive impact on strategic change; cognitive intention has indirect effect on strategic change explicitly; cognitive socialization and externalization has indirect effect on strategic change. From the perspective of integrity, entrepreneur cognition has a direct impact on strategic change. The conclusions of this study have positive implications for the optimization of entrepreneurial cognitive modeling and the promotion of strategic change.
\end{abstract}

\section{Introduction}

The enterpreneur play an important role in the survival and development of enterprises. Most of the enterprises in the environment are complex and dynamic, which face the difficults of competitors and technology innovation [1, 2]. So enterprises need to adjust or change the strategy according to the actual changes in the environment, and make strategic changes, only in this way, can the enterprises can survive and develop. Chinese enterprises should not only face the country fierce competition in the market field, but also to face the change of macro policy environment, Enterprises urgently need new theory to deal with the challenge of market change [3].At present, more and more attention has been paid to the strategic decision makers, and more attention has been paid to the factors such as cognitive process and behavior of entrepreneur [4-7]. However, the most of strategic management is based on the belief that both the environment and the organization are objective facts, and that these policies are developed through rational processes. But in fact, the ability of managers to digest all the information is limited, and there is no accurate method to make decision [8]. The basic source of strategic change is the conflict of strategic thinking. Strategic change is the enterprise in order to adapt to changes in the external environment. The strategic change from the cognitive perspective, that strategic change decision is affected by the changes in the external environment influence, cognitive influence causal relationship between actions and results and take strategic decisions subject to external environment, influence of entrepreneurial cognition on strategic change, can enterprises face more strategic choices, and be able to maintain long-term business the development trend of enterprises [9]. This paper draws lessons from the existing theory, consider the overall relationship framework and strategic change process of entrepreneurial cognition, the study of entrepreneur cognitive direct impact on the strategic change from theory, especially from the dynamic perspective focuses on the intermediary mechanism of knowledge creation process, and further take sample statistics and typical case analysis, influence an empirical analysis of the two variables between the model and its effect. 


\section{Theoretical knowledge analysis and hypothesis}

\section{A. Theoretical knowledge analysis}

The influence of entrepreneurs on the decision-making of enterprises strategic change is shown through the entrepreneural ability [10]. And entrepreneurs play a dominant role and sponsors in the process of strategy decision. Strategic decision process will inevitably be affected by entrepreneurial ability and innovation ability. The relationship between entrepreneurial capability and strategic capability plays a dominant role in the strategic decision-making process. Other abilities play a supporting role for entrepreneurs to obtain the information of degree of cognitive strategy and cognitive tendency of intellectual skills will affect the ability of the entrepreneur entrepreneurs. cognitive ability with different cognitive scope and depth is gradually developing and perfecting cultivating entrepreneurial cognition can improve the ability of the entrepreneur, the entrepreneur cognition by affecting entrepreneur ability size therefore directly influence on the corporate strategic change decision, entrepreneurial cognition of enterprise strategic change The logical relationship between reflected leather influenced by entrepreneurial ability this intermediate variables on entrepreneurial cognitive entrepreneur ability and strategic change, are shown as follows: the internal and external environment of the enterprise $\rightarrow$ entrepreneurial cognition: information acquisition; cognitive style; cognitive strategies; wisdom and skills $\rightarrow$ Entrepreneurial ability: strategic management ability; relationship; innovation ability; learning ability $\rightarrow$ Ability of enterprise strategic change opportunities.

In the above model can be seen: the entrepreneur cognition includes: information acquisition, cognitive tendency, four aspects of wisdom skills and cognitive strategies affect the ability of the entrepreneur, entrepreneur ability as intermediate variables, including strategic ability, management ability, ability, learning ability, innovation ability and opportunity ability. The influence of entrepreneurial cognition on the strategic change decision is influenced by the intermediate variable of entrepreneurial competence.

The strategic change of enterprises can play an important role in the success of entrepreneurs' cognition.

(a)Information acquisition: the acquisition of information refers to the amount of information available to entrepreneurs within a certain period of time. Information can be divided into: invisible and explicit information. Visible information refers to the experience of entrepreneurs, technology, cultures, habits, which belongs to the perceptual person. Hidden information is similar to the unique resources of the enterprise, which has an important role in the sustainable development of the enterprise. Both contact information and explicit information interaction, mutual transformation, and will form a unique entrepreneurial ability, entrepreneur ability of using this strategy change previous consequence analysis, make scientific and rational evaluation, summarize the experience and lessons, thus affecting the actual effect of strategic change. Entrepreneurs get the difficulty of information determines the entrepreneur cognition of the external environment, in a complex environment, entrepreneurs only got more than competitor information, and access to the information processing and utilization, and make decisions quickly, the internal and external environment to changing, enhance the advantages of the development of enterprises.

(b) Cognitive tendency: cognitive tendency refers to the influence of the factors such as personal behavior tendency, past successful experience and educational background and so on. Different entrepreneurs have different cognitive tendencies; there are significant differences between each individual. Positive cognitive tendencies are the thoughts and memories that will lead to pleasure, and negative cognitive tendencies can produce pessimistic thoughts and memories. With the positive cognitive tendency of entrepreneurs are willing to spend a lot of time and energy for business development in strategic change process, entrepreneurial cognition helps enterprise strategic decision to a certain extent, improve the ability of survival and development of enterprises. However, under certain circumstances, subordinates know that the cognitive tendency of entrepreneurs will selectively and tend to provide information, which will increase the cognitive tendencies of entrepreneurs, and ultimately the formation of cognitive rigidity. At this time, entrepreneurs will hinder the perception of enterprise strategic change decisions 
(c)Cognitive strategy: the cognitive model of entrepreneurs is cognitive strategy, there are two meanings: (1) through the social education background, geographical environment, and other factors to form a concept and thinking habits. (2) the means of processing the acquisition of information. Every entrepreneur's life experience, education background and work experience is different, and it results in each entrepreneur has faced different cognitive models of enterprise environment changes. Some entrepreneurs realize the change and make the positive response; some entrepreneurs do not realize the change of the external environment and produce the entrepreneur cognitive lag, thus adversely influence on enterprise strategic transformation decision making. Entrepreneurs should continue to break the 'inherent thinking mode' or 'cognitive lag', and create a cognitive strategy to adapt to environmental changes, and promote the implementation of enterprise strategic change decisions

\section{B. Hypothesis}

In the long process of practice, every enterprise has not exactly the same work experience, the way of thinking, as well as the concept of survival and development of enterprises, and forming their own unique cognitive style. Previous studies have shown that there are three dimensions of entrepreneurial cognition: Arrangement Cognitions, Willingness Cognitions and Ability Cognitions.

(a) Arrangement Cognitions:

The allocation of cognitive knowledge structure is required for entrepreneurs to realize enterprise creation and development, contact relationship, resources and assets, involving entrepreneurs how to use a special configuration to support their own skills and performance in specific areas

(b) Willingness Cognitions

Willingness cognition is the knowledge structure of the entrepreneur's commitment to the establishment and development of the enterprise, and is willing to accept the relevant views of the enterprise. Research shows that cognitive Willingness include some implementation dimensions: capturing the opportunity, including the new situation and looking for the possibility of strategic change, strategic change, orientation and motivation; commitment to limit their commitments including will put into practice and assume the risk and responsibility of the possibility of strategic change decision the opportunity to weigh, including; to complete the task and lose the chance to try and fail is worse than faith.

(c) Ability Cognitions

Ability Cognition is a kind of knowledge structure, which includes the skills, knowledge, values, and attitudes and so on. In the literature, there are three kinds of the ability of Entrepreneurs: cognitive diagnostic ability, including the conditions and the possibility of strategic change prospective evaluation, and understand the forward-looking strategic change affect the realization ability of the system of factors in the process; context knowledge, including the strategic change from prospective lessons learned in the process of implementation and the ability its application in specific situations; ability - the opportunity to match, including how to through the combination of new personnel, raw materials or products, in order to find the way to achieve the prospective strategic change ability.

\section{Simulation research}

\section{A. Sample selection and data collection}

According to the nature of the problem, this paper uses questionnaire survey to obtain relevant data. In the collection and analysis of data, this paper through the questionnaire method to obtain the initial one-time data, then the questionnaire of the measurement items of project analysis, the poor discriminability items to be deleted. On the basis of the factor analysis, the factors of the load dispersion and the significance of the item is not deleted, and finally according to the retention of the information extracted from the formal questionnaire data for statistical analysis.

\section{B. The measurements of parameters}

(a) Independent variables: entrepreneur cognition. About the operational measurement of entrepreneur cognition, there are few domestic literatures. In this paper, a model of scenario structure model is used to measure entrepreneur cognition". In this method, the existence and extent of 
entrepreneur cognition is based on the decision situation simulation method, which can be inferred according to the choices made by the respondents.

(b) Control variables.

In this paper, the control variables include three indicators, such as the size of the firm, the age of the firm, and the ownership of the enterprise.

(c) Dependent variable: enterprise strategic change

(d) Intermediate variable: knowledge creation process

C. Analysis method design

The formula is designed to analyze the influence of independent variables on dependent variables;

$$
\begin{aligned}
& S P_{u}=\alpha_{1}+\beta_{1} E C_{u}+\varepsilon_{1} \\
& K C P_{u}=\alpha_{2}+\beta_{2} E C_{u}+\varepsilon_{2} \\
& S P_{u}=\alpha_{3}+\beta_{3} E C_{u}+\varepsilon_{3}
\end{aligned}
$$

Where $\alpha$ is constant, $\beta$ means the matrix; $S P$ means the strategic change and $E C_{u}$ is entrepreneurial cognition $K C P$ is the knowledge creation process. $\varepsilon$ represents the estimation error.

\section{Data analysis and results}

\section{A. Descriptive statistics and correlation coefficient matrix analysis}

Table 1 shows the mean and standard deviation of the main variables, and the correlation coefficient of person. The results show that the significant positive correlation between entrepreneurial cognition and strategic change, there is a significant relationship between the effects of different dimensions of entrepreneurial cognition and knowledge creation process, and the process of knowledge creation has significant influence on the forward-looking strategic change. The control variables have a significant impact on entrepreneurial cognition, knowledge creation process and strategic change. The results show that the overall effect of the regression model is ideal. (Where EC represents entrepreneurial cognition; $\mathrm{E}$ is the abbreviation of entreprese and $\mathrm{C}$ is the abbreviation of

\begin{tabular}{|c|c|c|c|c|c|c|c|c|c|c|c|c|c|}
\hline variable & $\overline{\mathrm{x}}$ & $\begin{array}{l}\mathrm{RM} \\
\mathrm{SE}\end{array}$ & 1 & 2 & 3 & 4 & 5 & 6 & 7 & 8 & 9 & 10 & 11 \\
\hline E C & $\begin{array}{l}16.5 \\
53\end{array}$ & $\begin{array}{l}3.24 \\
3\end{array}$ & & & & & & & & & & & \\
\hline Socialization & $\begin{array}{l}19.4 \\
16\end{array}$ & $\begin{array}{l}3.39 \\
2\end{array}$ & $\begin{array}{l}0.44 \\
3\end{array}$ & & & & & & & & & & \\
\hline Combination & $\begin{array}{l}14.2 \\
8\end{array}$ & $\begin{array}{l}3.52 \\
4 \\
\end{array}$ & $\begin{array}{l}0.37 \\
2 \\
\end{array}$ & $\begin{array}{l}0.37 \\
5\end{array}$ & & & & & & & & & \\
\hline Externalization & $\begin{array}{l}10.4 \\
10\end{array}$ & $\begin{array}{l}2.62 \\
7\end{array}$ & $\begin{array}{l}0.25 \\
2\end{array}$ & $\begin{array}{l}0.17 \\
8\end{array}$ & $\begin{array}{l}0.28 \\
8\end{array}$ & & & & & & & & \\
\hline Arrangement C & $\begin{array}{l}9.93 \\
8\end{array}$ & $\begin{array}{l}2.53 \\
1\end{array}$ & $\begin{array}{l}0.28 \\
7\end{array}$ & $\begin{array}{l}0.07 \\
8\end{array}$ & $\begin{array}{l}0.01 \\
6\end{array}$ & $\begin{array}{l}0.00 \\
5\end{array}$ & & & & & & & \\
\hline Willingness C & $\begin{array}{l}8.88 \\
1\end{array}$ & $\begin{array}{l}2,57 \\
1\end{array}$ & $\begin{array}{l}0.28 \\
9\end{array}$ & $\begin{array}{l}0.46 \\
8\end{array}$ & $\begin{array}{l}0.43 \\
7\end{array}$ & $\begin{array}{l}0.30 \\
8\end{array}$ & $\begin{array}{l}0.08 \\
6\end{array}$ & & & & & & \\
\hline Ability C & 9.46 & $\begin{array}{l}2.59 \\
9\end{array}$ & $\begin{array}{l}0.29 \\
1\end{array}$ & $\begin{array}{l}0.57 \\
8\end{array}$ & $\begin{array}{l}0.33 \\
9\end{array}$ & $\begin{array}{l}0.24 \\
8\end{array}$ & $\begin{array}{l}0.09 \\
2\end{array}$ & $\begin{array}{l}0.08 \\
5\end{array}$ & & & & & \\
\hline E age & $\begin{array}{l}5.17 \\
7 \\
\end{array}$ & $\begin{array}{l}2.36 \\
5 \\
\end{array}$ & $\begin{array}{l}-0.3 \\
69 \\
\end{array}$ & $\begin{array}{l}-0.1 \\
58 \\
\end{array}$ & $\begin{array}{l}-0.0 \\
83\end{array}$ & $\begin{array}{l}-0.0 \\
63 \\
\end{array}$ & $\begin{array}{l}-0.0 \\
002\end{array}$ & $\begin{array}{l}-0.2 \\
34 \\
\end{array}$ & $\begin{array}{l}-0.1 \\
35 \\
\end{array}$ & & & & \\
\hline E scale & $\begin{array}{l}2.39 \\
8 \\
\end{array}$ & $\begin{array}{l}1.09 \\
6\end{array}$ & $\begin{array}{l}-0.6 \\
08 \\
\end{array}$ & $\begin{array}{l}-0.3 \\
75 \\
\end{array}$ & $\begin{array}{l}-0.3 \\
21 \\
\end{array}$ & $\begin{array}{l}-0.2 \\
75 \\
\end{array}$ & $\begin{array}{l}-0.1 \\
99 \\
\end{array}$ & $\begin{array}{l}-0.2 \\
83 \\
\end{array}$ & $\begin{array}{l}-0.2 \\
43 \\
\end{array}$ & $\begin{array}{l}-0.2 \\
61 \\
\end{array}$ & & & \\
\hline State-owned E & $\begin{array}{l}0.22 \\
1 \\
\end{array}$ & $\begin{array}{l}0.41 \\
6 \\
\end{array}$ & $\begin{array}{l}-0.2 \\
13 \\
\end{array}$ & $\begin{array}{l}-0.0 \\
91 \\
\end{array}$ & $\begin{array}{l}-0.0 \\
94 \\
\end{array}$ & $\begin{array}{l}-0.0 \\
122 \\
\end{array}$ & $\begin{array}{l}-0.0 \\
46 \\
\end{array}$ & $\begin{array}{l}-0.0 \\
29 \\
\end{array}$ & $\begin{array}{l}-0.0 \\
17 \\
\end{array}$ & $\begin{array}{l}-0.1 \\
36 \\
\end{array}$ & $\begin{array}{l}0.47 \\
5 \\
\end{array}$ & & \\
\hline Collective E & $\begin{array}{l}0.18 \\
6\end{array}$ & $\begin{array}{l}0.39 \\
0\end{array}$ & $\begin{array}{l}-0.0 \\
32\end{array}$ & $\begin{array}{l}-0.1 \\
49\end{array}$ & $\begin{array}{l}-0.1 \\
29\end{array}$ & $\begin{array}{l}-0.1 \\
19\end{array}$ & $\begin{array}{l}-0.0 \\
58\end{array}$ & $\begin{array}{l}-0.0 \\
47\end{array}$ & $\begin{array}{l}-0.1 \\
02\end{array}$ & $\begin{array}{l}-0.0 \\
98\end{array}$ & $\begin{array}{l}0.07 \\
5\end{array}$ & $\begin{array}{l}0.05 \\
5\end{array}$ & \\
\hline private E & $\begin{array}{l}0.16 \\
4 \\
\end{array}$ & $\begin{array}{l}0.37 \\
1 \\
\end{array}$ & $\begin{array}{l}-0.0 \\
42 \\
\end{array}$ & $\begin{array}{l}0.03 \\
4 \\
\end{array}$ & $\begin{array}{l}0.08 \\
4 \\
\end{array}$ & $\begin{array}{l}0.09 \\
7 \\
\end{array}$ & $\begin{array}{l}-0.0 \\
15 \\
\end{array}$ & $\begin{array}{l}0.02 \\
0 \\
\end{array}$ & $\begin{array}{l}-0.0 \\
87\end{array}$ & $\begin{array}{l}0.03 \\
7 \\
\end{array}$ & $\begin{array}{l}-0.0 \\
23 \\
\end{array}$ & $\begin{array}{l}0.09 \\
0 \\
\end{array}$ & $\begin{array}{l}-0.2 \\
36 \\
\end{array}$ \\
\hline
\end{tabular}
cognition; $\overline{\mathrm{x}}$ is the average value; RMSE is the Root mean square error)

Tab1. Descriptive statistics and correlation coefficient matrix 


\section{B. A regression analysis of the relationship between entrepreneurial cognition and strategic change}

Tab2 the multiple regression results of enterprise strategy

\begin{tabular}{|l|l|l|l|l|l|}
\hline variable & Model 1 & Model 2 & Model 3 & Model 4 & Model 5 \\
\hline Constant term & $21.566(0.487)$ & $19.819(0.970)$ & $19.646(0.860)$ & $19.883(0.904)$ & $17.093(1.315)$ \\
\hline E age & $-0.162(0.088)$ & $-0.131(0.089)$ & $-0.154(0.087)$ & $-0.155(0.088)$ & $-0.119(0.088)$ \\
\hline E scale & $-1.624(0.166)$ & $-1.547(0.169)$ & $-1.534(0.167)$ & $-1.543(0.169)$ & $-1.419(0.172)$ \\
\hline State-owned E & $-0.886(0.515)$ & $-0.982(0.513)$ & $-0.854(0.508)$ & $-0.775(0.513)$ & $-0.889(0.507)$ \\
\hline Collective E & $-0.236(0.485)$ & $-0.258(0.482)$ & $-0.098(0.481)$ & $-0.125(0.484)$ & $-0.073(0.478)$ \\
\hline private E & $-0.247(0.500)$ & $-0.314(0.497)$ & $-0.122(0.495)$ & $-0.252(0.495)$ & $-0.214(0.491)$ \\
\hline Arrangement C & & $0.145(0.070)$ & & & $0.150(0.069)$ \\
\hline Willingness C & & & $0.181(0.067)$ & & $0.152(0.072)$ \\
\hline Ability C & & & & $0.149(0.068)$ & $0.093(0.072)$ \\
\hline $\mathrm{R}^{2}$ & 0.403 & 0.415 & 0.422 & 0.416 & 0.439 \\
\hline $\mathrm{R}^{2}$ after adjusement & 0.390 & 0.399 & 0.407 & 0.400 & 0.419 \\
\hline The value of F & 29742 & 4.247 & 7.234 & 4.847 & 4.624 \\
\hline
\end{tabular}

Table 2 shows the regression analysis of the relationship between entrepreneurial cognition and strategic change. It can be seen that, for the three control variables, the age and the size of the enterprise have a significant negative impact on strategic change, that is, the longer the enterprise, the larger the scale, the more detrimental to the occurrence of strategic change. The above analysis results show that there are significant differences in the process of entrepreneurial cognition, knowledge creation and strategic change

All in all, the empirical results show that the different dimensions of entrepreneurial cognition have positive effects on corporation strategic change. Specifically, the allocation of cognition has a direct positive impact on strategic change; cognitive intention has indirect effect on strategic change explicitly; cognitive socialization and externalization has indirect effect on strategic change. From the perspective of integrity, entrepreneur cognition has a direct impact on strategic change.

\section{Summary}

The paper introduces the logical relationship between entrepreneurial cognition and strategic change, and states the influence of strategic change through entrepreneurial cognition. Then the peper propose the hypothesis of entrepreneurial cognition. Finally, according to the hypothesis of the paper, sstablish regression model of entrepreneurial cognition and strategic change, through questionnaire data and quantitative analysis, the results show that entrepreneurial cognition have positive effects on corporation strategic change. Specifically, the allocation of cognition has a direct positive impact on strategic change; cognitive intention has indirect effect on strategic change explicitly; cognitive socialization and externalization has indirect effect on strategic change. From the perspective of integrity, entrepreneur cognition has a direct impact on strategic change. The conclusions of this study have positive implications for the optimization of entrepreneurial cognitive modeling and the promotion of strategic change.

\section{References}

[1] Sadler-Smith E. Cognitive style: Some human resource implications for managers [J]. International Journal of Human Resource Management, 1998, 9(1): 185-202.

[2] Yang L. Empirical study on the relationship between entrepreneurial cognitions and strategic change momentum: The moderating effect of organizational knowledge structures [J]. Management Decision, 2015, 53(5): 957-983. 
[3] Augier M, Teece D J. Dynamic capabilities and the role of managers in business strategy and economic performance [J]. Organization Science, 2009, 20(2): 410-421.

[4] Mitchell R K, Smith J B, Morse E A, et al. Are entrepreneurial cognitions universal? Assessing entrepreneurial cognitions across cultures [J]. Entrepreneurship: Theory and Practice, 2002, 26(4): 9-33.

[5] Binbin Z, Jiangtao D, Mingxing L, et al. The Empirical Research on Independent Technology Innovation, Knowledge Transformation and Enterprise Growth [J]. Journal on Innovation and Sustainability. RISUS ISSN 2179-3565, 2012, 3(2).

[6] Krueger N F, Carsrud A L. Entrepreneurial intentions: applying the theory of planned behavior [J]. Entrepreneurship \& Regional Development, 1993, 5(4): 315-330.

[7] Glade W P. Approaches to a theory of entrepreneurial formation [J]. Explorations in Economic History, 1967, 4(3): 245-259.

[8] Rodríguez, A., Nieto, M. J. Does R\&D Offshoring Lead to SME Growth Different Governance Modes and the Mediating Role of Innovation, Strategic Management Journal, 2015, Article first published online: 4 AUG 2015 DOI: 10.1002/smj.2413.

[9] De Jong, B. A., Elfring, T. How Does Trust Affect the Performance of Ongoing Teams The Mediating Role of Reflexivity, Monitoring, and Effort. Academy of Management Journal, 2010, 53(3): 535-549

[10] Sabherwal, R., Becerra-Fernandez, I. An Empirical Study of the Effect of Knowledge Management Processes at Individual, Group, and Organizational Levels. Decision Sciences, 2003, 34(2): 225-260. 